\title{
Significance of Cultural Heritage Preservation in Sustainable Cultural Tourism: Muradiye Complex in Bursa, Turkey
}

\author{
Selen Durak ${ }^{1}$, Saliha Tupal Yeke ${ }^{2}$, Tulin Vural Arslan ${ }^{3}$
}

\begin{abstract}
Cultural tourism has become one of the important sectors of tourism in recent years with the growing awareness on cultural heritage. As being aware of the tourism potential of cultural heritage sites, policy makers pay special attention to preservation of these sites. However, the increasing number of visitors depending on the promotion of culture and history began to endanger the sustainability of heritage sites. In order to ensure the balance between preservation and utilization, researchers investigated the ways for welcoming large number of visitors without risking the sustainability.

Bursa, as one of the recent UNESCO World heritage sites in Turkey, has a growing potential in terms of cultural tourism with its peculiar Ottoman urban pattern including building complexes called kulliyes. This situation caused an increase in the number of visitors. Muradiye Kulliye is one of the attracting places in Bursa in terms of its symbolic and historic characteristics including a mosque, a madrasa, a bath and the tombs of earlier Ottoman Sultans. This paper aims to describe the practices in terms of preservation for ensuring the sustainability of the complex.
\end{abstract}

Keywords: Sustainability, Cultural Tourism, Heritage, Preservation, Bursa, Turkey

\section{Introduction}

Cultural tourism, one of the most important branches of tourism industry, has recently become more popular as a result of increase in awareness of cultural assets. One of the actions taken to increase the popularity of tourism, which has an undeniable contribution to social, cultural and economic development, is to facilitate transportation to targeted attraction points. In 1980s, when tourism first started to develop in Turkey, three S's, namely sea, sand and sun were emphasize in tourism policies. However, these concepts have recently reached saturation and they are now insufficient to increase competitiveness in tourism. As a result, individuals have started to prefer alternative tourism types, which make it possible to learn new things, be more active and comfortable and to address one's interests. Cultural tourism is leading these alternatives. The purpose of this study is to analyze the restoration of the Muradiye Complex in Bursa with reference to cultural tourism as an example to restoration projects carried in the light of providing sustainability, use and conservation of cultural assets in Turkey (Şahin, 2012).

${ }^{1}$ Assoc. Prof. Dr., Uludag University, Faculty of Architecture, Department of Architecture, Bursa, 16059 Turkey

${ }^{2}$ M. Arch., Uludag University, Faculty of Architecture, Department of Architecture, Bursa, 16059 Turkey ${ }^{3}$ Assoc. Prof. Dr. Uludag University, Faculty of Architecture, Department of Architecture, Bursa, 16059 Turkey 


\section{Cultural Heritage and Tourism}

Countries have developed and competitive products and strategies to increase their share in world tourism within the scope of their holistic solution needs and existing potentials. As a result, they have come up with the concept of "alternative tourism". Opinions regarding the emergence of alternative tourism vary a lot.

The reasons for emergence of alternative tourism are:

- Decrease in resources and deterioration in their qualities,

- $\quad$ Sustainable tourism understanding,

- The concept of spreading tourism throughout the year

- Consumers are bored of classical tourism and have different expectations,
- $\quad$ creating different vacation options for consumers

Cultural tourism, one of these alternative tourism types, has grown significantly in line with the evolving expectations and preferences of tourists. Tourists want to visit more diffierent and authentic places, as a result of which there has been an increase in travels to cultural sites. World Tourism Organization estimates 37\% of tourism travels correspond to cultural tourism and that this demand will increase by $15 \%$ every year.

\section{Development of the Concept of Cultural Heritage and Preservation in the World}

The concept of cultural heritage and preservation was first discussed at the first International Congress of Architects and Technicians of Historic Monuments organized by the International Museums Organization in Athens in 1931. In this conference, also known as the Athens Conference, it was suggested that areas surrounding historical sites, groups of historic monuments and landscapes should be preserved. These principles were officially adopted in Italy in 1932 under the title of 'Carta del Restauro' (Restoration Charter).

Later on awareness, regarding heritage preservation increased and on 16.11.1945 UNESCO (United Nations Educational, Scientific and Cultural Organization) was founded by 20 countries, including Turkey. "The European Cultural Convention", of which Turkey is a party to, was prepared by the Council of Europe that was founded in 1949 and signed on 19.12.1954 and came into force on 05.05.1955.

The Venice Charter, which was written in Venice in 1964 and considered to be one of the most important documents in the field of preservation, was adopted as the conclusion charter of the First International Congress of Architects and Specialists of Historic Buildings. The International Council on Monuments and Sites (ICOMOS) was founded in 1965 in Warsaw as a result of the Venice Charter's recommendation on founding an international council to work actively in preservation of monuments and sites. The main objectives of the $2^{\text {nd }}$ Council are preservation of monuments and sites, developing principles, techniques and policies and last but not least supporting any kind of research and development.

The 17th General Conference of UNESCO, which took place between 17 October - 21 November 1972 in Paris, adopted on 16 November 1972 the Convention concerning the Protection of the World Cultural and Natural Heritage in order to promote cultural and 
natural assets, which have universal values and are accepted common heritage of the whole humanity, in the world; to create awareness to preserve the abovementioned universal heritage in the society and to cooperate to keep cultural and natural values, which have been damages for different reasons, alive.

Internationally important, thus noteworthy natural formations, monuments and sites that are worth preserving are listed in the "World Heritage List". Following the application of member states, which have adopted the convention, to UNESCO, a group of experts from the International Council on Monuments and Sites (ICOMOS) and International Union for Conservation of Nature and Natural Resources (IUCN) evaluates the applications. Upon completion of all steps of the applications, the World Heritage Committee gives the final decision regarding the status of the world heritage. As of 2015, there are 1031 cultural and natural properties listed in the UNESCO's World Heritage List in the world, 802 of which are cultural, 197 natural and 32 mixed properties (cultural/natural) (Turkish Republic Ministry of Culture and Tourism General Directorate of Cultural Assets and Museums. World Heritage List, 2016). This convention especially emphasizes the interdependency of states and the need for cooperation in preserving the world heritage and thus bases the preservation of the common heritage of humanity on the cooperation between countries (Akipek, 2001).

\section{Legislation Regarding Development of Cultural Heritage Preservation in Turkey}

Westernization process in Ottoman Empire started in the first quarter of the $19^{\text {th }}$ century and had two very important indicators: "setting written rules" and "institutionalization". As a matter of fact, attitude and regulations regarding historical sites are also based on the Tanzimat Reform Era, in which westernization efforts were first seen. Charters on Historic Artifacts dated 1869, 1874 and 1884 entered into force in this era and aimed at preserving portable properties. They also established rules regarding bringing archeological artifacts dating back to Greek, Roman and Byzantine eras together announcing them government property, preventing smuggling abroad, preserving and displaying in museums.

In the $4^{\text {th }}$ Charter on Historic Artifacts dated 1906, architectural artifacts reflection of Turkish-Islam art were also included in the scope of the preservation of archeological artifacts dating back to Greek, Roman and Byzantine eras.

Between 1923-1950 in the New Republican Era, most of the institutes and rules were adopted as they were in the Ottoman Empire. Commission on Preservation of Ancient Monuments carried on with its functions as approved by the Charter in 1924 and evaluated applications coming from the Board of Education, Istanbul Municipality and Istanbul Directorate for Foundations, deciding whether properties need to be preserved or not.

Between 1951 and 1973, the Supreme Council of Antiquities and Monument Real Estate (GEEAYK) was founded per Law dated 1951 and numbered 5805, which can also be considered as the beginning of modern preservation works. GEEAYK was founded as a central committee in charge of establishing rules for preservation, restoration, repair, and renovation of ancient buildings and monuments having architectural and historic properties, monitoring the practices and auditing the projects. 
Provisions regarding preservation remained just a part of development plan laws mainly aiming at regulating planning and implementation activities. They gained a legislative framework only in 1973. The Law on Ancient Monuments dated 25.04.1973 and numbered 1710 prepared for systematic preservation of architectural and historic monuments and sites with their surroundings and broke new grounds in many aspects. In this law, the term ancient monument was defined and explained, details regarding monuments and complexes were given, the concept of a site was elaborated on differentiating between historic site, archeological site and natural site.

The Law on Ancient Monuments numbered 1720 failed to satisfy preservation works. As a result, it was abolished on 21 July 1983 as per the 1982 Constitution Act and was replaced by the Code of Protection of Cultural and Natural Properties dated 2863. The Code of Protection dated 2863 was amended by the Code numbered 3386 that came in to effect in 1987. The Code dated 2863 was rearranged by the Code dated 14.07.2004 numbered 5226 so that existing legal system in historic and natural environment protection could be adapted with the international standards and corporate structure could be strengthened.

\section{Effects of Tourism on Cultural Heritage}

Culture and cultural properties of each and every nation are of utmost value. However, these values can be sustainable only when they are protected and good managed. Museums or displaying and protection of historic sites gain importance in that regards. However, there are certain negative effects caused by industrialization, fast urbanization, obsession to possess 2 real estates and tourism. Unplanned and uncontrolled development of tourism resulted in an increase in levels of use of these cultural properties causing it to be used over its bearing capacity. When the resources are used over their bearing capacities, they get damaged and even destroyed. Tourists are potential users of cultural properties. There is an important connection between tourism and cultural heritage. For this reason, cultural tourism can play an active role in protection and management of cultural heritage. Considering tourists are among the user groups of cultural properties, tourism needs to be controlled effectively (Meydan Uygur \& Baykan, 2007).

\section{Policies Regarding Sustainability of Cultural Tourism}

Whereas the development of tourism and increase in numbers of tourists have a positive impact on economies, they also result in a visible damage on the environment. Damages on the environment, natural, cultural and historic fabric have in return harmed not only tourism but also the countries, where such touristic activities were carried out. Although, in the past tourism was discussed only in terms of its goods and advantages, its environmental impacts started to be seen. In line with the popularity of the concept of "sustainable development" in 1980's, the concept of "sustainable tourism" was mentioned in the literature for the first time. Sustainable tourism means protecting, preserving and developing natural, historic, cultural, social and esthetic values, which are the source of tourism (Demirel, 2010). 
Tourism activities, which continue increasingly all around the world, have caused irreversible damages or damages, which would take long time to recover on natural, socio-cultural resources, which actually set the basis for tourism. Negative impacts of tourism are generally seen as a result of consumption based collective use. This farreaching use, which is also defined as mass tourism, together with un-planned constructions and over-capacity use result in irrecoverable problems. International institutions such as United Nations and the World Bank organized various conferences as a reaction to these problems as of 1970 s and as a result of these conferences the concept of "sustainable tourism" was born (Eser et. al., 2010).

Historic cities are both subjects and targets of cultural tourism. Tourism creates economic values, encourages investments in cultural heritage, promotes local venues and services, keep local traditions and important days and products alive, thus benefits cities. However, when it is not good managed, it damages perception of local population regarding their living space, causing them to be alienated against their cultural identity, and commodifying cultural properties and traditions. Hence, benefits of such tourism cannot be sustained (Dedehayir, 2012). Local authorities need to attach priority cultural and historic heritage of cities rather than tourism income to be able to have sustainable cultural tourism. Differences, local cultures and beliefs should be taken into account in cultural tourism practices. Citizens of the city should adopt cultural tourism; whereas tourism should respects needs of the local society and visitors should be informed accordingly.

\section{Case Study: Bursa Muradiye Complex in Terms of Sustainable Cultural Tourism}

Bursa was included in the UNESCO World Heritage List, where in total 1007 world heritage sites are listed, as the Turkey's 12th and world's 998th heritage site with an outstanding universal value as a result of evaluation its "nomination dossier" titled "Bursa and Cumalikızık: the Birth of the Ottoman Empire" Khans Area involving Orhan Ghazi Kulliye and its environs, Hüdavendigar (Murad I) Kulliye, Yıldırım (Bayezid I) Kulliye, Yeşil (Mehmed I) Kulliye, Muradiye (Murad II) Kulliye and Cumalıkızık Village prepared by the Bursa Metropolitan Municipality.

Muradiye Complex is the last kulliye (complex) constructed by Ottoman Sultans in Bursa. It was constructed by Murat II between 1425 and 1426 and gave its name to the district, it is located. Muradiye Complex is composed of a mosque, madrasa, bath, hospice and tombs. Some of the tombs were constructed additionally in Mehmed the Conquerer, Bayezid II and Suleyman the Magnificent Eras. There are 13 tombs within the borders of the Muradiye Complex, which were constructed in the $15^{\text {th }}$ and $16^{\text {th }}$ centuries by various Ottoman empires for their relatives and one more tomb located separately than the others because of the road on the west side of the complex. The most important of these tombs is the Tomb of Murad II, constructed by his son Mehmed the Conqueror. This tomb's interior space is $13.45 \mathrm{~m} \times 13.45 \mathrm{~m}$ large and is covered by a dome fitted on an octagon pulley carried by four pillars and four feet connected with arches and its surrounding vault. The walls of the tomb were constructed with bricks (two layers) and rubble stones (one layer). The tombs were restored by Bursa Metropolitan Municipality. 
Modern preservation practices gained importance as of the adoption the Venice Charter in 1964. In 1980's the importance of the management was first started to be mentioned in the international arena for a holistic preservation. The first examples were seen on sites that are in the World Heritage List and in Europe, especially in England. In Turkey, the problems and mistakes in the preservation field were noticed by also non-academic circles in 2000's and the need for modern regulations increased. As a result, structural reforms were carried out mostly in 2004 in line with the European Union harmonization process and the related legal regulations were then updated.

A similar acceleration in preservation field could also be seen in Bursa in 2000's. Bursa Metropolitan Municipality being in the first place, district municipalities made tenders of restoration projects and implementation. Restoration works on twelve tombs started in November 2012 by the Bursa Metropolitan Municipality and ended in October 2015.

Restoration works in the tombs were shaped in line with the decisions of the scientific committee formed in accordance with resolutions of the Regional Council of Cultural and Natural Heritage in Bursa. Restoration was carried out using modern techniques not intervening in the authentic construction techniques. One of the most important details, found out as a result, was ornaments with classical hand-drawn patterns revealed after scraping. The findings suggest that the inner of outer structures of the tombs were not damaged during the earthquake in 1855. They also give information about special handmade patterns dating back to the end of $15^{\text {th }}$ and the beginning of the $16^{\text {th }}$ centuries.

The Muradiye Complex is located on the north-western foothills of the Bursa Castle and was constructed by Sultan Murad II. The large complex is composed of a mosque, a madrasa, a bath, an imaret (soup-kitchen), a fountain and tombs. Like in previous examples of Complexes of Sultan Orhan, Sultan Murad I, Sultan Bayezid I and the Green dome, the Muradiye Complex was also constructed in north-western suburbs of the city to provide an expansion. However, it was planned on a straight line not scattered like others. The mosque's construction started in May 1425 and ended in November 1426. The tomb of Sultan Murat II was constructed in front of the mosque after his death in 1451. Hazire (burial area reserved for special people in mosques) of the mosque became a dynasty grave, since many sultan's sons and courtiers were also buried in that area.

Among courtiers there were Huma Hatun, the mother of Mehmet II, the Conquerer, Sultan Cem, Şehzade Mustafa (son of Süleyman, the Magnificient) and his mother Mahidevran Hatun, his siblings and his wife Gülşah Hatun, his midwife Gülbahar Hatun, sons of Sultan Selim I, Şehzade Mahmut and Şehzade Ahmet, their wives Gülruh Hatun, Şirin Hatun, his daughter-in-law Mükrime Hatun. There are nineteen people resting in twelve tombs. In addition, there are also people worked in the mosque and madrasa and their relatives buried in front of the madrasa on the right hand side of the entrance in the garden.

Restoration works of the tombs in the Muradiye Complex, which is on the World Cultural Heritage List, and thus has the title of "World Heritage with Outstanding Universal Values". It is possible to see a small example of paradise promised in every sacred book in the garden of the Muradiye Complex. This Complex has the potential to be one of the most important cultural destinations in Bursa with its imaret, madrasa, bath, including the Ottoman House, Museums of Ulu Umay and Hüsnü Züber because 
Muradiye is not just a graveyard, it is also a memory of centuries (Y1lmaz, 2015).

Figure 1. Layout Plan of the Muradiye Complex

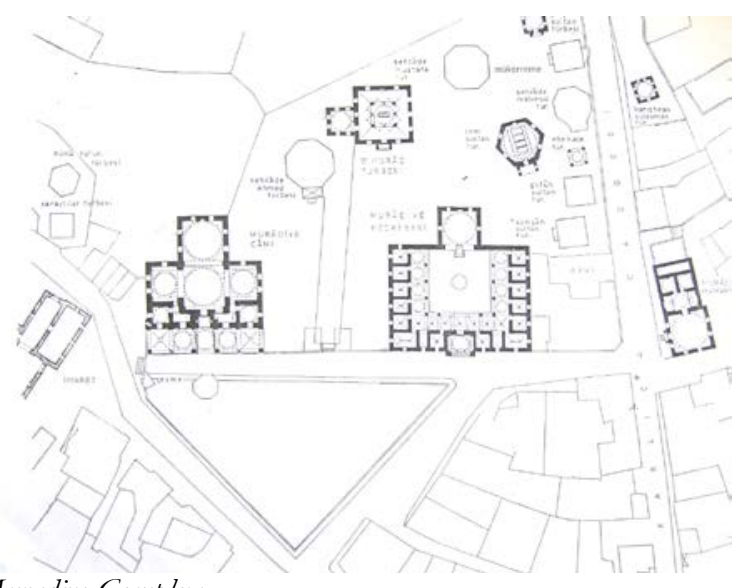

The Muradiye Complex has an important role in forming cultural tourism. One of the biggest strengths that would help fulfill the potential of cultural tourism is accessibility. Since it is located in the center of Bursa and very close to other cities in the region like Istanbul and Izmir, many tourist prefer here. In addition to being centrally located, the region attracts also pedestrian tourists, since it is easily accessible using public transportation.

The Complex reflects characteristics of the architecture in the rise of the Ottoman Empire, which has a very important place in the history. Moreover, it also offers a rich diversity in historic monuments with its mosque, madrasa, bath, imaret and tombs. In addition to social events organized in this area, tours organized by travel agencies increase the number of visitors, as well. Although there has been an increase in promotions following the inclusion in the World Heritage List, tourism consciousness still needs to be raised. Sufficient budgets should be given for promotion and marketing. The number of facilities around the attraction points should be increased. Pedestrian routes should be connected within the ancient city center. In line with the increase in interest for historic and cultural tourism, the potential of alternative tourism types increase, as well. Training seminars and cultural seminars organized by the local governments will help raise awareness among local community and tourists regarding tourism and cultural heritage.

\section{Restoration practices and techniques used in Muradiye Complex}

Preservation of architectural heritage is a part of cultural and environmental development. Architectural restoration means restoring an ancient building, which has a structural authenticity value and historic and cultural importance in accordance with its authenticity using authentic materials and construction techniques or preserving it with the least number of interventions (Benli, 2012).

As mentioned in the Venice Charter, "A monument is inseparable from the history to 
which it bears witness and from the setting in which it occurs. The moving of all or part of a monument cannot be allowed except where the safeguarding of that monument demands it or where it is justified by national or international interest of paramount importance". The fundamental approach in preserving cultural properties is to provide continuous maintenance. Damages determined following analyses should be removed, their impacts should be decreased. The preservation techniques that could be used for these purposes are reinforcement, completion, renewal, reconstruction, cleaning and transfer.

In reinforcement works, materials, building system and the ground, on which the building is located, are reinforced. If only a part of a building is damaged or destroyed, it is completed using modern or traditional materials to reflect how it was when it was first designed, which is called completion. Changing life styles and functions result in a need for creating programs which would promote different kinds of uses of the buildings. In such cases, renewal methods are applied. Another technique is reconstruction, in which a building, which is completely ruined, reconstructed based on old documents like photos and drawings. Cleaning is to clear cultural properties and urban sites of additions that do not have any historic and esthetic value destroying the integrity. Generally, a cultural property is preserved on site as a matter of principle. However, in case there is no alternative, it might be sometimes impossible to preserve a cultural property or historic site at its own location due to high public interest or very important public works, geological structure and natural disasters. In that case, a cultural property or site might be transferred to a new pre-determined suitable location (Ahunbay, 2004).

Main reasons for deterioration in historic monuments are long-term natural factors, natural disasters, use-related damages, soil properties, mistakes in structural design, use of wrong materials, poor workmanship, use of details and user-related problems. A sustainable preservation policy needs to not only take local cultures into account but also taking precautions for wide decentralization. This means, all decision-making levels (central, regional, local) in planning should involve experts in preservation. Nevertheless, protection of architectural heritage should not be restricted to only experts. Protection of architectural heritage requires a new long term approach attaching the required importance to qualitative criteria and right proportions refusing an old-fashioned narrow-minded approach based options and targets. Holistic preservation is also under the responsibility of local authorities and requires participation of citizens (Serdaroğlu, 2006).

\section{Structural Interventions}

In the first stage of restoration practices, buildings should be cleared of un-authentic elements that were added later. For this reason, first outer facades of all tombs were first scraped of additional cement covering. Cracks, which posed statistical problems, were strengthened with seams and injections. All grouts were made using brick dust mortar clearing cement mortars. Tarnishing caused by humidity and carbon and biological degradation on the surface were also removed. 
Figure 2. Restoring the vaults of Murat II. Tomb Roof

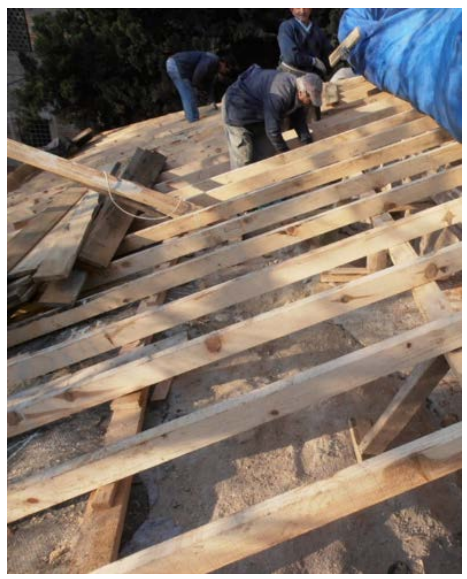

In order to avoid water rising from the ground and to drain rainwater, drainage was made on foundation walls. Lead coatings were removed, clay and straw plasters were renewed and recovered with lead.

Knotted iron grilles of the windows were first cleared of the pain and repainted after antirust was applied. Marble window frames and cracks on all marble surfaces were improved. Chemical methods were used to clean carbon and fume off the surfaces.

\section{Conservation of Hand-Drawn and Malakari (Gypsery made using trowel) Ornaments}

First and foremost detailed photos were taken for documentation purposes in all of the tombs. Then surveying of the current situation were prepared. After research scraping, it was decided to preserve which era in accordance with the Committee Decision. Restoration projects of that era were prepared and a section on the dome was left as an addition from other periods. Since cemented parts revealed during scraping damaged the structure, all surfaces were cleared of cement. Since cement causes salinisation in the structure, the surfaces, where cement was scraped, were desalinated with distilled water.

Micro-injection was performed to re-attach plaster on the surface, where there were some local detachments. Cracks and detachments on the surface were completed using authentic mortar. Amount of plasters that were removed during cement scraping were determined and were replaced by traditional plasters. All surfaces were cleared of dust and dirt.

Malakari, of which traces could be found, were completed. The ones that completely vanished were remade based on authentic parts. On partially standing malakari ornament, traces of red lead and gold were found. In line with the approved project, red lead, gold smear and gold foil were applied on some part. Having completed the aforementioned steps approved by the Committee Decision, other ornaments were improved and the lost parts were remade in accordance with the project. 


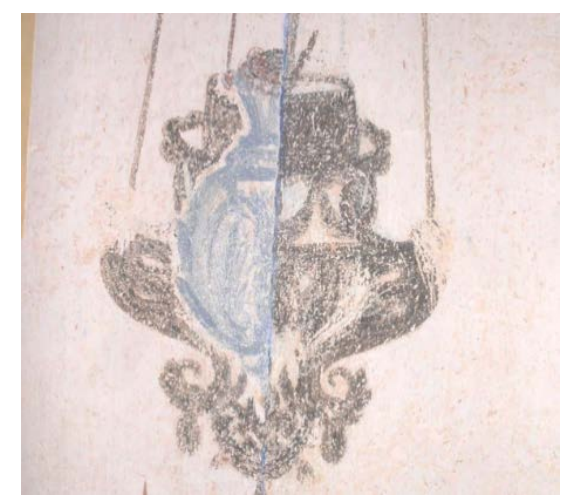

Figure 3. Hand-made Ornaments on the Mibrab of Murat II. Tomb

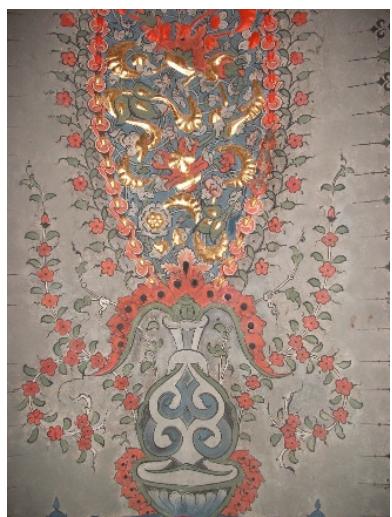

Figure 4. Hand-made Ornaments and Malakari on the wall of Shehrade Mahmut Tomb

\section{Restoration of Wall Tiles}

In tombs, where there were tiles on the wall, first current situation of all facades was documented through photographs prior to restoration. All deterioration, cracks, lacking parts, detachments were registered. All tiles were chemically and mechanically cleaned. The ones that were in poor condition were conserved using chemical methods to strengthen the glaze. Later on joints were cleaned and renewed. The tiles, which were detached while joints were cleaned, back surfaces of the tiles were cleaned and desalinated. The damage given by cement was decreased by performing desalination on the surface, where tile was to be attached. Finally, all the gaps on the tiles and surfaces were completed and coloured.

\section{Restoration of Wooden Elements}

All woodworks, wooden shutters, "kündekar" (technique of placing small pieces of wood side by side to form a design) doors were cleaned and fumigated. Worm holes were filled with sawdust and glue. The missing parts were repaired with suitable woods. Shellac varnish was applied on wooden surfaces so that wood could breathe.

Edirnekari-style (synchronized and unique dance of colors with flowers) ornaments were revealed on wooden surfaces on ceiling eaves after scraping. Consequently, wooden surfaces were cleaned, conserved and improved. 


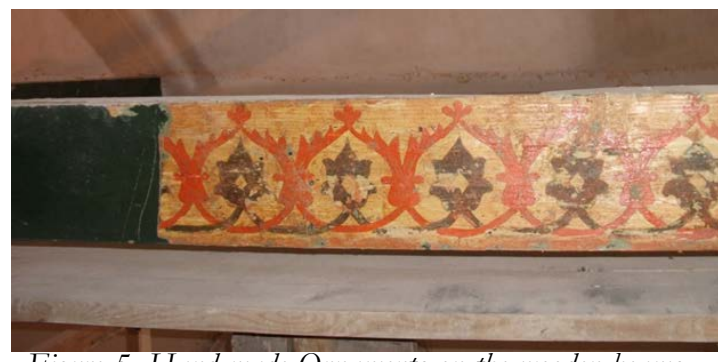

Figure 5. Hand-made Ornaments on the wooden beams of Murat II. Tomb

\section{Conclusion}

Tourism, which is a rapidly evolving industry, creates a very important multiplier effect on destinations that can adopt the right approaches in this field. Diversification in tourism and new tendencies arising out of this diversification obligate tourism regions to reposition and restructure themselves. When we look at the tourism regions at world scale, we notice that there has been a significant increase not only in the numbers of tourists but also in the number of facilities. At this point, Turkey should be represented in the international arena with its brand cities. Brands to be formed should give information about existing cultural heritage attraction points and encourage tourists to visit these sites. At the same time, it should be a goal to adopt an authentic, enthusiastic, community-oriented, product-based, sustainable, educational cultural policy, which is motivated by values, encourages local community to take part in planning and management of tourism and has maximum income.

The fact that there are a lot of risks in promoting tourism in natural and urban sites shows us that a high level of sensitivity should be shown in doing that. While it is important to promote cultural values and address all people at international level on one hand, on the other hand, it is of crucial importance to secure these values and prevent irreversible damages. Cultural tourism management is necessary for preserving these natural and urban sites, which are shaped by tourism. Many protection sites use nowadays these management plans for management of historic sites to promote preservation and new developments. All responsibilities should be fulfilled so that cultural tourism can be sustainable in the Muradiye Complex and the restored textures in the buildings can be transferred to next generations. 


\section{References}

Ahunbay, A.Z., "Historical Environment Preservation And Restorastion", The Building Information Center, 2004, Istanbul (Ahunbay, A.Z., "Tarihi Çevre Koruma Ve Restorasyon”, Yapi Endüstri Merkezi, 2004, İstanbul)

Akipek, Serap "Consideration Of Engagement About World Cultural And Natural Heritage Preservation", Ankara University, 2001, Ankara (Akipek, S., "Dünya Kültürel ve Doğal Mirasinin Korunmasina Dair Sözleşmenin Değerlendirilmesi, Ankara Üniversitesi, 2001, Ankara)

Gülhan Benli, "Restoration In Old Buildings" İstanbul Aydin University, Faculty Of Engineering And Architecture, Department Of Architecture, 2012, Istanbul (Gülhan Benli, "Eski Eser Yapida Restorasyon Yapmak", İstanbul Aydin Üniversitesi, Mühendislik Mimarlik Fakültesi, Mimarlik Bölümü, İstanbul)

Dedehayir, H., "Sustainable Cultural Tourism", Promotion And Protection Of Environment And Cultural Heritage Foundation, 2012, Istanbul (Dedehayir, H., "Sürdürülebilir Kültür Turizmi”, Çevre Ve Kültür Değerlerini Koruma Ve Tanitma Vakfi, 2012, İstanbul)

Demirel, H., "Sustainability On Tourism", General Directorate Of The Ministry Of Culture And Tourism, 2010, Ankara (Demirel, H., "Turizmde Sürdürülebilirlik”, Kültür Ve Turizm Bakanliği Tanitma Genel Müdürlüğ̈̈, 2010, Ankara)

Eser, S., Dalgin, T., Çeken, H., "Sustainable Cultural Tourism: Efes Sample”, Ege Journal Of Geography, 19/2, 2010, 27-34, Izmir (Eser, S., Dalgin, T., Çeken, H., "Sürdürülebilir Kültür Turizmi: Efes Örneği”, Ege Coğrafya Dergisi, 19/2, 2010, 27-34, İzmir)

Meydan Uygur, S., Baykan, E., "Cultural Tourism And Effects Of Tourism On Cultural Property", Faculty Journal Of Commerce And Tourism Training, 2007, Issue: 2, Ankara (Meydan Uygur, S., Baykan, E., "Kültür Turizmi Ve Turizmin Kültürel Varliklar Üzerindeki Etkileri”, Ticaret Ve Turizm Eğitim Fakültesi Dergisi Yil: 2007 Sayi: 2, Ankara)

Şahin, F., "Cultural Tourısm Potentıal Of Eskısehır, Current Sitatıon And Guidelınes", General Directorate Of The Ministry Of Culture And Tourism, Directorate Of Cultural Heritage Conservation District Board Of Eskisehir, Dıssertatıon, 2012, Eskısehır (Şahin, F., "Eskişehir İlinin Kültür Turizmi Potansiyeli: Mevcut Durum Ve Öneriler”, Kültür Ve Turizm Bakanlığı Eskişehir Kültür Varlıklarını Koruma Bölge Kurulu Müdürlüğü, Uzmanlık Tezi, 2012, Eskişehir)

Serdaroğlu, B.,” General Conceptual Overview On Restoration “, Maltepe University, Institute Of Science And Technology, ” Post Graduate Thesis, 2006, Istanbul (Serdaroğlu, B.,”Restorasyona Genel Kavramsal Bakiş“, Maltepe Üniversitesi Fen Bilimleri Enstitüsü, Yl Tezi, 2006, İstanbul)

T.C. Kültür Ve Turizm Bakanliği Kültür Varliklari ve Müzeler Genel Müdürlüğü. Dünya Miras Listesi, 2016. (Turkish Republic Ministry of Culture and Tourism General Directorate of Cultural Assets and Museums. World Heritage List, 2016) (Accessed on August 17, 2016 from http://www.kulturvarliklari.gov.tr/TR,44423/dunya-miras-listesi.html)

Yilmaz, S., "Muradiye: Living Spirit Of Ottoman Empire", Journal Of Time In Bursa, October 2015, Bursa (Yilmaz, S., "Yaşayan Osmanli Ruhu: Muradiye”, Bursa’da Zaman Dergisi, Ekim 2015, Bursa) 